\title{
One-stage Versus Two-stage Reduction of Malunited Femoral Fracture with Shortening
}

\author{
AR Sulaiman, (M Med Ortho), H Eskandar, (MD), WI Faisham (M Med Ortho) \\ Department of Orthopaedics, School of Medical Sciences, University Sains Malaysia, 16150 Kota Bharu, Kelantan, \\ Malaysia
}

\begin{abstract}
Reduction of a malunited femoral diaphyseal fracture can be achieved by osteotomy and immediate internal fixation or gradual skeletal traction followed by delayed internal fixation. We retrospectively reviewed 27 patients with malunited and shortened femur. Nine patients with mean shortening of $4.7 \mathrm{~cm}$ (2.5-10.0) underwent acute one-stage reduction and gained 2.5 to $5.0 \mathrm{~cm}$ length. Eighteen patients with mean shortening of $5.3 \mathrm{~cm}$ (3.5 to 9.0) underwent twostage reduction and gained 2.0 to $5.0 \mathrm{~cm}$ length. There was no paralysis in either group. No infection occurred in the one-stage procedure. Intramedullary fixation demonstrated superior results compares to plate fixation.
\end{abstract}

Key Words:

Femur, mal-union, Limb length discrepancy, Acute reduction

\section{INTRODUCTION}

Malunion of femoral diaphyseal fracture may lead to abnormal mechanical axis of the lower limbs or limb length discrepancy. Shortened femur can be corrected with either distraction osteogenesis or operative reduction. Distraction osteogenesis involves gradual lengthening of the bone over a period of time with an external fixator and carries with it the risk of joint stiffness and pin tract infection ${ }^{1,2}$. Reduction of malunion may be achieved by either one stage or two stage reduction. The one stage procedure involves breaking down of the malunion and acute reduction, while the two stage technique involves breaking down of the malunion followed by gradual reduction with skeletal traction or external fixation device. One-stage reduction of malunion with shortening is associated with extensive tissue injury and nerve paralysis ${ }^{2-4}$. In two-stage reduction, the force of traction is generally less and is applied over a period of time to minimise neurovascular injury. However, this technique requires an additional surgery and exposure to problems inherent in the use of skeletal traction.

The aim of this study was to compare the outcome of onestage to two-stage reduction of malunited femur fracture with shortening.

\section{METHODS AND SURGICAL PROCEDURES}

We retrospectively reviewed the folders of 27 patients who were treated for femoral shortening (due to malunion) with either one-stage or two-stage reduction between 1996 and 2004 at our institution. Choice of procedure was based on surgeon's preference.

One-stage reduction involved an open osteotomy and correction of the deformity (which included shortening). Fixation was achieved by either intra-medullary nailing or plating (Fig. 1). In cases where full reduction was not achievable due to excessive soft tissue tension, shortening of the femur was performed.

Two-stage reduction involved open osteotomy at the malunion site, insertion of a proximal tibia pin and weight skeletal traction. Desired femoral length was attained by gradual weight increase of traction in the ward, unless the patient developed complications such as paraesthesia or pin loosening. After about 2 weeks, fixation of the fracture, with either a nail or a plate, was performed.

\section{RESULTS}

24 out of 27 patients studied (89\%) sought initial treatment from a traditional healer. Nine patients subsequently underwent one-stage reduction (Table I) and 18 patients had two-stage reduction (Table II). The average age of patients treated was 19.8 years old (range 8 - 38) for one-stage reduction and 20.6 years old $(14-27)$ for two-stage reduction. The average limb shortening at presentation for the 2 groups was $4.7 \mathrm{~cm}$ (range 2.5-10.0) and $5.3 \mathrm{~cm}$ (range3.5 to 9.0) respectively. The delay in surgical treatment was between 1.4 to 34.6 months (average 8 months) in the first group and 1.0 to 29.8 months (average 7.8 months) in the second group.

The mean overall increase in length was $4.2 \mathrm{~cm}(1-9 \mathrm{~cm})$. In the one-stage surgery, mean correction of $3.9 \mathrm{~cm}(2-5 \mathrm{~cm})$ was achieved compared to $4.4 \mathrm{~cm}(1$ to $9 \mathrm{~cm})$ result for the two-stage procedure. There were no neurovascular 
One-stage Versus Two-stage Reduction of Malunited Femoral Fracture with Shortening

Table I: List of patients treated with one stage procedure

\begin{tabular}{|c|c|c|c|c|c|c|c|c|}
\hline Ptn & $\begin{array}{c}\text { Age } \\
\text { (year-s) }\end{array}$ & $\begin{array}{c}\text { delay } \\
\text { (mon-th) }\end{array}$ & Short $(\mathrm{cm})$ & $\begin{array}{l}\text { Length } \\
\text { acquired } \\
(\mathrm{cm})\end{array}$ & $\begin{array}{l}\text { method of } \\
\text { fixation / } \\
\text { bone graft }\end{array}$ & $\begin{array}{c}\text { Duration of } \\
\text { of healing } \\
\text { (days) }\end{array}$ & $\begin{array}{c}\text { hosp stay } \\
\text { (days) }\end{array}$ & Compli- cation \\
\hline 1 & 10 & 3.5 & 5.5 & 4.5 & $\mathrm{P} / \mathrm{N}$ & 16 & 7 & $\mathrm{~N}$ \\
\hline 2 & 21 & 3.1 & 3 & 3 & $\mathrm{I} / \mathrm{N}$ & 11 & 7 & $\mathrm{~N}$ \\
\hline 3 & 38 & 6.0 & 5 & 5 & $\mathrm{P} / \mathrm{N}$ & 17 & 3 & $\mathrm{~N}$ \\
\hline 4 & 14 & 4.9 & 3 & 3 & $\mathrm{P} / \mathrm{N}$ & 15 & 3 & $\mathrm{~N}$ \\
\hline 5 & 23 & 13.1 & 4 & 4 & $\mathrm{P} / \mathrm{Y}$ & 19 & 9 & broken plate \\
\hline 6 & 20 & 4.0 & 2.5 & 2 & $\mathrm{I} / \mathrm{N}$ & 17 & 13 & $\mathrm{~N}$ \\
\hline 7 & 19 & 1.4 & 5 & 5 & $\mathrm{P} / \mathrm{N}$ & 22 & 9 & $\mathrm{~N}$ \\
\hline 8 & 25 & 34.6 & 10 & 4 & $\mathrm{I} / \mathrm{Y}$ & 52 & 53 & $\mathrm{~N}$ \\
\hline 9 & 8 & 1.4 & 5 & 5 & $\mathrm{P} / \mathrm{N}$ & 18 & 6 & $\mathrm{~N}$ \\
\hline mean & 19.8 & 8.0 & 4.7 & 3.94 & & 21 & 12 & \\
\hline
\end{tabular}

Ptn=patient; Delay= Period from injury to treatment; short=limb length discrepancy before surgery; I= intramedullary interlocking nail; $\mathrm{P}=$ Plate and screws; $\mathrm{Y}=$ bone graft was used; $\mathrm{N}=$ bone graft was not used.

Table II: List of patients treated with two stages procedure

\begin{tabular}{|c|c|c|c|c|c|c|c|c|}
\hline ptn & $\begin{array}{c}\text { Age } \\
\text { (years) }\end{array}$ & $\begin{array}{c}\text { delay } \\
\text { (months) }\end{array}$ & $\begin{array}{l}\text { Short } \\
(\mathrm{cm})\end{array}$ & $\begin{array}{l}\text { Length } \\
\text { acquired } \\
\text { (cm) }\end{array}$ & $\begin{array}{l}\text { method of } \\
\text { fixation / } \\
\text { Bone graft }\end{array}$ & $\begin{array}{c}\text { Duration of } \\
\text { healing } \\
\text { (weeks) }\end{array}$ & $\begin{array}{c}\text { hosp stay } \\
\text { (days) }\end{array}$ & Complication \\
\hline 10 & 25 & 3.6 & 4 & 2.5 & $\mathrm{P} / \mathrm{Y}$ & 32 & 25 & non union \\
\hline 11 & 27 & 3.1 & 6 & 6 & $\mathrm{P} / \mathrm{N}$ & 18 & 59 & non union \\
\hline 12 & 22 & 3.0 & 4 & 4 & $\mathrm{P} / \mathrm{Y}$ & 13 & 34 & $\mathrm{~N}$ \\
\hline 13 & 17 & 11.1 & 5 & 5 & $\mathrm{P} / \mathrm{Y}$ & 14 & 15 & Infection \\
\hline 14 & 14 & 2.0 & 3.5 & 3.5 & $\mathrm{P} / \mathrm{N}$ & 16 & 35 & $\mathrm{~N}$ \\
\hline 15 & 24 & 1.4 & 4 & 4 & $\mathrm{P} / \mathrm{N}$ & 18 & 39 & $\mathrm{~N}$ \\
\hline 16 & 23 & 5.8 & 5 & 1 & $\mathrm{P} / \mathrm{N}$ & 25 & 14 & $\begin{array}{l}\text { Infection and } \\
\text { non-union }\end{array}$ \\
\hline 17 & 19 & 2.3 & 5 & 5 & $\mathrm{I} / \mathrm{Y}$ & 24 & 20 & infection \\
\hline 18 & 16 & 2.0 & 5 & 2.5 & $\begin{array}{l}\text { Full length } \\
\text { cast/ } \mathrm{N}\end{array}$ & 8 & 38 & $\begin{array}{l}\text { infection after } \\
\text { osteotomy }\end{array}$ \\
\hline 19 & 14 & 1.0 & 6 & 3.5 & $\mathrm{P} / \mathrm{Y}$ & 16 & 38 & No \\
\hline 20 & 16 & 4.1 & 7 & 5 & $\mathrm{P} / \mathrm{N}$ & 51 & 19 & broken plate \\
\hline 21 & 21 & 29.8 & 4.5 & 2.5 & $\mathrm{I} / \mathrm{Y}$ & 31 & 34 & $\mathrm{~N}$ \\
\hline 22 & 25 & 36 & 4 & 4 & $\mathrm{I} / \mathrm{N}$ & 20 & 37 & $\mathrm{~N}$ \\
\hline 23 & 22 & 2.7 & 4 & 3 & $\mathrm{P} / \mathrm{N}$ & 12 & 22 & $\mathrm{~N}$ \\
\hline 24 & 26 & 4.1 & 6 & 6 & $\mathrm{I} / \mathrm{Y}$ & 18 & 27 & $\mathrm{~N}$ \\
\hline 25 & 15 & 1.7 & 6 & 6 & $\mathrm{P} / \mathrm{N}$ & 18 & 36 & $\mathrm{~N}$ \\
\hline 26 & 21 & 11.8 & 9 & 9 & $\mathrm{P} / \mathrm{Y}$ & 17 & 36 & $\mathrm{~N}$ \\
\hline 27 & 23 & 14.8 & 7 & 6 & $\mathrm{P} / \mathrm{Y}$ & 32 & 30 & $\mathrm{~N}$ \\
\hline mean & 20.6 & 7.8 & 5.3 & 4.4 & & 21.3 & 31 & \\
\hline
\end{tabular}

Ptn=patient; Delay= period from injury to treatment; short=limb length discrepancy before surgery; ; I= intramedullary interlocking nail; $\mathrm{P}=\mathrm{Plate}$ and screws; $\mathrm{Y}=$ bone graft was used; $\mathrm{N}=$ bone graft was not used.

complications in either group. Almost all patients (except patients 8 and 16) had limb length discrepancy reduced to less than $3 \mathrm{~cm}$ (Table II). In patient 8 , an acute correction of $4 \mathrm{~cm}$ was achieved, leaving the patient with $6 \mathrm{~cm}$ of residual shortening. Patient 16 who sustained an open fracture and had multiple surgeries following the initial injury developed complication of skeletal traction and subsequently achieved only $1 \mathrm{~cm}$ length correction.

The average duration from reduction to union in the onestage reduction was 21.0 weeks as compared to 21.3 weeks for the two-stage procedure. The average hospitalization period for the one-stage acute procedure was 12 days ( 7 to 53days) as compared to 31 days (14 to 59days) for the twostage procedure.
Of the patients treated with two-stage reduction, four (22.2\%) developed superficial infection (Table II). Infection occurred in one patient after primary osteotomy and was successfully treated with antibiotics. The second stage surgery was not performed as he was instead treated using a full length cast until union. The remaining 3 patients developed infection after the second stage of surgery and were successfully treated with antibiotics. There were no cases of infection in the one-stage.

All patients treated with intramedullary nail fixation achieved union. Five patients treated with plate fixation developed aseptic nonunion, of whom four were in the twostage procedure group. All of these patients required revision surgery involving removal of plate followed by interlocking nail fixation. A bone graft was used in 7 of 19 


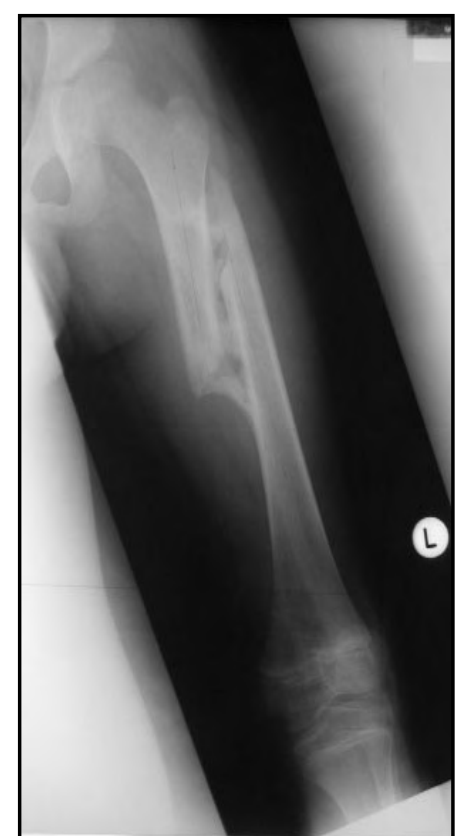

Fig. 1a: Radiograph shows mal-union shaft of femur.

cases treated with plate fixation. Nonunion occurred in 2 patients with bone graft and 3 patients without bone graft.

\section{DISCUSSION}

Untreated fractures resulting in malunion are not rare in Malaysian society, mainly because many patients seek initial treatment from traditional bone healers. Shortening, angular and rotational malalignments are frequent findings, and subsequent treatment may be difficult. Typically, a discrepancy of $2 \mathrm{~cm}$ or less does not require correction ${ }^{1,5,6}$.

The bone lengthening procedure that utilizes distraction osteogenesis achieves soft tissue elongation through regeneration of tissue. In acute reduction of malunion, this depends on the ability of nerve, vessels and muscles to regain their original length following the period of shortening and scarring due to the trauma. Therefore, the one stage reduction procedure is contraindicated when conditions such a previous bone grafting procedure, infection, nerve injury or extensive soft tissue scarring are present ${ }^{7}$.

The one-stage femoral reduction procedure is thought to be associated with extensive tissue dissection and complications such as infection, nerve paralysis, hardware failure and nonunion $^{2-4,8}$. Estimates of maximum acute lengthening that can be tolerated range between $4 \mathrm{~cm}$ and $7 \mathrm{~cm}^{7,8}$. The greatest increase in length found in this study for one-stage procedures was $5 \mathrm{~cm}$. For patients with a severe shortening (i.e., $8 \mathrm{~cm}$ ) the one stage technique is not a suitable choice.

Two-stage reduction procedures allow the surgeon to control gradual lengthening and minimise the risk of nerve paralysis.

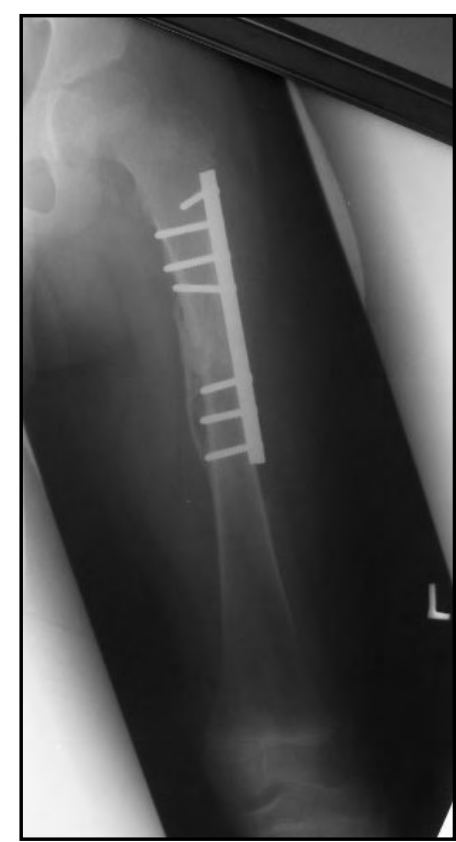

Fig. 1b: Radiograph shows plate fixation after osteotomy and reduction.

We were able to achieve correction up to $9 \mathrm{~cm}$ (patient 26) with this technique. However this procedure requires a prolonged hospital stay and higher rates of infection as compared to the one stage procedure.

We note a higher nonunion rate in plate stabilisation as compared to use of the intramedullary nail technique. Plate fixation requires massive soft tissue stripping in order to achieve good reduction, and causes devascularisation of the bone which may contribute to nonunion. Similarly, Muller ${ }^{9}$ reported 4 failures of plate fixation out of 11 cases. Disuse osteoporosis associated with stress to the plate and screw following acute lengthening can also lead to failure of union.

A few authors recommend the use of bone grafting for all acute lengthening procedures to ensure union ${ }^{2,7}$. However, we could not justify the necessity of bone grafting in our study. With time, the fracture malunion will remodel and soft tissue will contract. One cannot draw clear conclusions from published studies about a firm cut off time after which acute correction should not be attempted. We found no association between time elapsed from injury to initiation of treatment and complication of treatment.

\section{CONCLUSION}

Malunited femur with up to $5.0 \mathrm{~cm}$ shortening is treatable via a one stage reduction procedure. Shortening of more than $5.0 \mathrm{~cm}$ may be treated with two stage reduction but risk of infection related to skeletal fixation should be considered when choosing treatment methodology. Nail fixation provides better rate of union compared to plate fixation. 
One-stage Versus Two-stage Reduction of Malunited Femoral Fracture with Shortening

\section{REFERENCES}

1. Kaufman KR, Miller LS, Sutherland DH. Gait asymmetry in patients with limb-length inequality. J Pediatr Orthop; 1996; 16(2): 144-50.

2. Whittle AP. Mal-united Fracture. In: Campbell's Operative Orthopaedics. 10th ed. Mosby-Year Book Inc; 2003: 3090-7.

3. Cauchoix J, Morel G. One stage femoral lengthening. Clin Orthop 1978; 136: 66-73.

4. Herron LD, Amstutz HC, Sakai DN. One stage femoral lengthening in the adult. Clin Orthop 1978(136): 74-82.

5. Brand RA, Yack HJ. Effects of leg length discrepancies on the forces at the hip joint. Clin Orthop 1996; 333: 172-80.

6. Liu XC, Fabry G, Molenaers G, Lammens J et al. et al. Kinematic and kinetic asymmetry in patients with leg-length discrepancy. J Pediatr Orthop; 1998; 18(2): 187-9.

7. Murray DW, Kambouroglou G, Kenwright J. One-stage lengthening for femoral shortening with associated deformity. J Bone Joint Surg 1993; 75B: 566-71.

8. Kempf I, Grosse A, Abalo C. Locked intramedullary nailing: Its application to femoral and tibial axial, rotational, lengthening, and shortening osteotomies. Clin Orthop 1986; 212: 165-73.

9. Muller KH, Strosche H, Scheuer I. Plate osteosynthesis in posttraumatic deformities of the femoral shaft. Arch Orthop Trauma Surg 1984. 103(5): 303-19. 